\title{
Om Holger Danske og Holger-fejden
}

af forskningsstipendiat, museumsinspektør Ole Kongsted, Musikhistorisk Museum

Det kongelige Biblioteks viste 9. nov. 1995 - 31. jan. 1996 en udstilling på Slotsholmen om komponisten og hofkapelmesteren F.L. Ae. Kunzen.

I forbindelse hermed skildres den berømte og berygtede Holger-fejde - operaen Holger Danske blev kvalt $i$ en operafejde, som i lige så hoj grad var en sprogfejde og en politisk kamp.

En Person af bekiendt stor Talent og fuldkommen Indsigt i alt hvad der henhører til General-Bassen, til at componere, synge og spille paa Claveer, agter ved sin Ankomst hertil efter Paaske derudi at give Undervisning paa en grundig, kort og let Maade. De, som maatte have Lyst til at betiene sig af ham, vilde behage i Forveyen at melde sig hos Kammerraad Bærens paa Nørregade nr. 48 ...".

Således blev F. L. Ae. Kunzen introduceret for det københavnske musikpublikum i Adresseavisen i 1785, og i 4 år - indtil Holger Danskes opførelse i 1789 levede han som musikinformator i hovedstaden i det håb, at der skulle blive en stilling til ham på teatret. Det blev der ikke - ikke i første omgang i hvert fald - og balladen omkring Holger Danske virkede ikke ligefrem befordrende på hans ansættelsesmuligheder.

For at forstå den opsigt operaen vakte, og de udpræget fjendtlige følelser den forårsagede, er det nødvendigt dels at se nærmere på teksten og dens forudsætninger, dels at forstå, hvorledes det danske samfund var indrettet anno 1789. Jens Baggesen hentede ideen til sit værk hos den tyske digter Christoph Martin Wieland i dennes værk Oberon. Hos Wieland hedder helten imidlertid ikke Holger Danske, men Huon de Bordeaux, hvilket skyldes, at grundstammen i Wielands digt er hentet fra den gamle franske 'chanson de geste' af samme navn. Her berettes om, at helten på vej til Babylon møder dværgen Auberon. Wieland skriver, at han på dette sted i sit værk tager sig den frihed at udskyde den oprindelige Auberon, der var søn 
af Julius Caesar og en fe, til fordel for den Oberon, vi kender fra Chaucer og fra Shakespeares A Midsummer Night's Dream og som er alfernes konge. Wieland troede, at der var tale om 2 væsener, mens der i virkeligheden er tale om en person, hvilket nyere forskning har vist - den samme person, som har gennemgået mange og højst forskellige metamorfoser. Han kendes i Nibelungenlied under navnet Alberich og optræder i Wagners operatrilogi Nibelungens Ring som en figur, der er diametralt modsat den Wieland-Baggesenske Oberon i karakter. Sammenstillingen af Oberon og Titania skylder vi Shakespeare, der hentede navnet Titania fra Ovids $M e$ tamorfoser.

Baggesen har ikke fulgt Wieland sla-

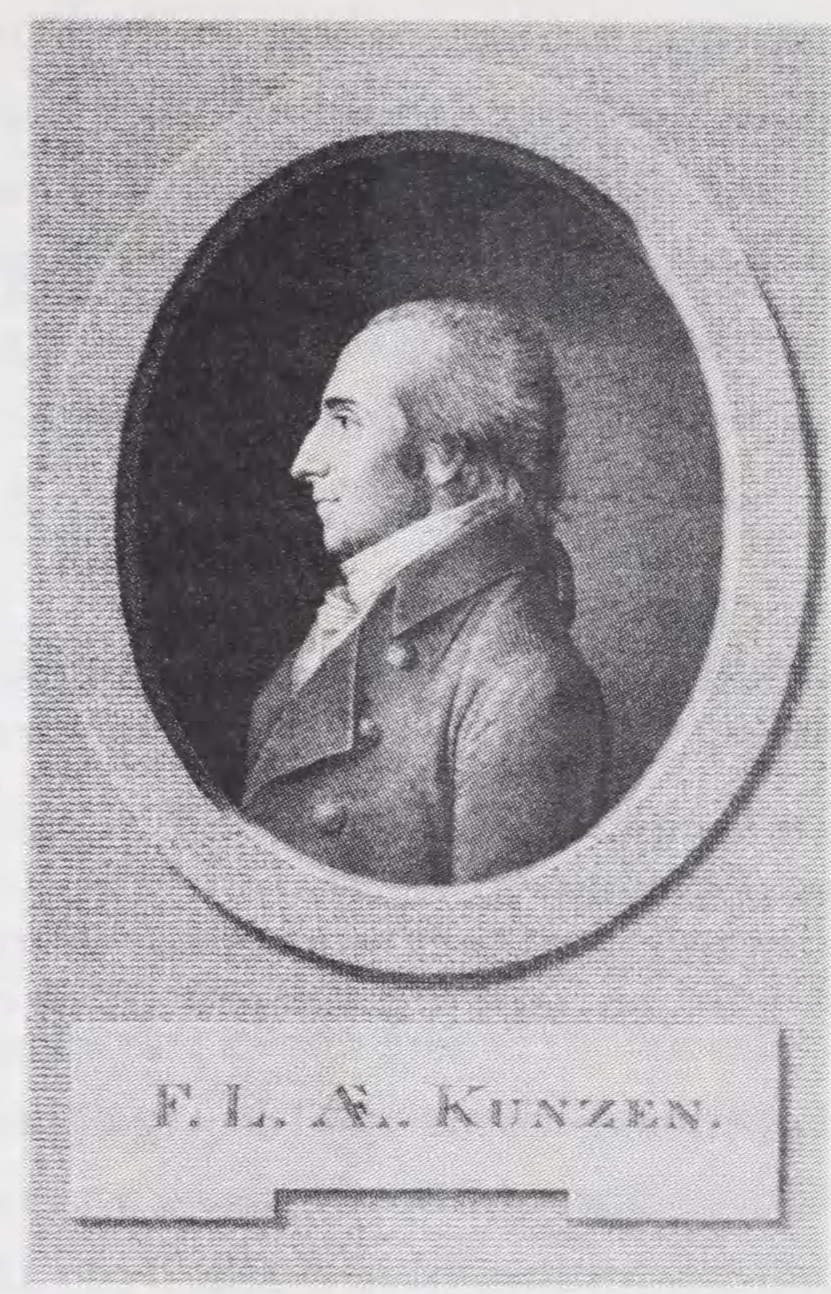

Friedrich Ludwig Aemilius Kunzen (17611817). Kobberstik af J.H. Lips, 1809.

visk. Også han har taget sig digteriskefriheder. Ifølge Wieland skal helten hugge hovedet af prins Langulaffer og trække nogle tænder ud af munden på sultan Buurman, men som Baggesen skrev:

„Man vil uden Tvivl tilgive mig, at jeg har sparet Sultanen sine Tænder, og Langulaffer sit Hoved, da det er en saa egen Sag at miste sligt paa Skuepladsen“.

Historien om Holger Danske (Ogier le Danois) stammer ligesom historien om Huon le Bordeaux fra oldfransk heltedigtning. Baggesen støtter sig formentlig på den gamle danske folkebog Kong Olger Danskis Kronicke som Christiern Pedersen bearbejdede fra fransk og udgav i 1534 og som i stadige optryk var folkelig læsning op i 1800 -tallet.

Baggesens tekstbog udkom nogle måneder før operaens premiere. Professor Rasmus Nyerup skrev herom i Minerva:

„Nu, da Baggesen har givet os den Wielandske Holger Danske, begynde skikkelige Folk igien at erkyndige sig om hin Ridderroman, der fordum moroede Konger, 
Fyrster og Riddersmænd, men nu ved Tidens Længde var nedsiunket til blot at være Lecture for Bønder, Kielderfolk og dem i Nyboder ..."

Allerede på dette tidspunkt - d.v.s. inden premieren - begyndte enkelte kritiske røster at hæve sig; man var ikke indforstået med, at „den danske Nationalhelt skulle haanes ved at blive kastet ind paa Scenen som en eventyrlig, sværmende Pralhals, for med Triller og Roulader at enervere det Folk, paa hvis Mod og Kraft han var et symbol“. Baggesen blev øjensynlig forskrækket over denne reaktion og besluttede sig til at forandre Holger - sandt at sige også det eneste nordiske indslag i dette østerlandske festfyrværkeri - til Huon de Bordeaux. Kunzen havde ingen indvendinger, men det havde derimod teatrets førsteelsker, Michael Rosing; han ville ikke høre tale om forandring - han havde sat næsen op efter at spille nordisk helt $\mathrm{i}$ rustning, og det kunne der minsandten ikke laves om på.

Premieren var d. 31. marts 1789. Teaterhistorikeren Overskou skriver herom:

„Kunzens henrivende, friske og gratiøst flydende Melodier med glimrende og smagfulde Forsiringer i Bravoursagerne, den vekslende pikante og grandiose Behandling af det instrumentale, Jfr. Møllers brillante og sjælfulde Udførelse af Rezia, de snart lystige, snart storartede Kor, de skønne Danse, prægtige orientalske Dragter, rige Optog og herlige Tableauer begejstrede Publikum til stormende Bifald."

Operaen gik for fulde huse 6 gange mellem d. 31. marts og d. 17. april. Efter at operaen var spillet 3. gang, anmeldte Johann Clemens Tode operaen; han slog fast, at operaen var en succes, og han roser i øvrigt de gode sang- og skuespilpræstationer samt dette flotte udstyr:

„Holger Danskes Skiæbne er bestemt. Stykket giør unægteligen saa herlig en Virkning paa Theatret, som nogen anden Oper. Musikken roses af Læg og Lærd, baade Hr. Kuntzens og Hr. Baggesens Arbeid har lykkeligen staaet sine Prøver ..."

Holger Danskes skæbne var imidlertid aldeles ikke „bestemt“. Netop som succesen syntes at være i hus, begyndte en proteststorm at rejse sig. Holger-fejden - et begreb i dansk musik-, litteratur- og teaterhistorie, der voksede til at blive veritabelt dansk/tysk opgør - var i gang. Modstanden kom fra forskellige lejre med forskellige argumenter, byens begavede litterater skrev side op og side ned i Københavns dengang talrige periodica: Nyeste Kjobenhavnske Efterretninger om larde Sager, Aftenposten, Kritik og Antikritik, Hertha, Minerva og mange flere. Ingen kunne blive enige med nogen om noget, og snart var det på det nærmeste alles kamp mod alle. 


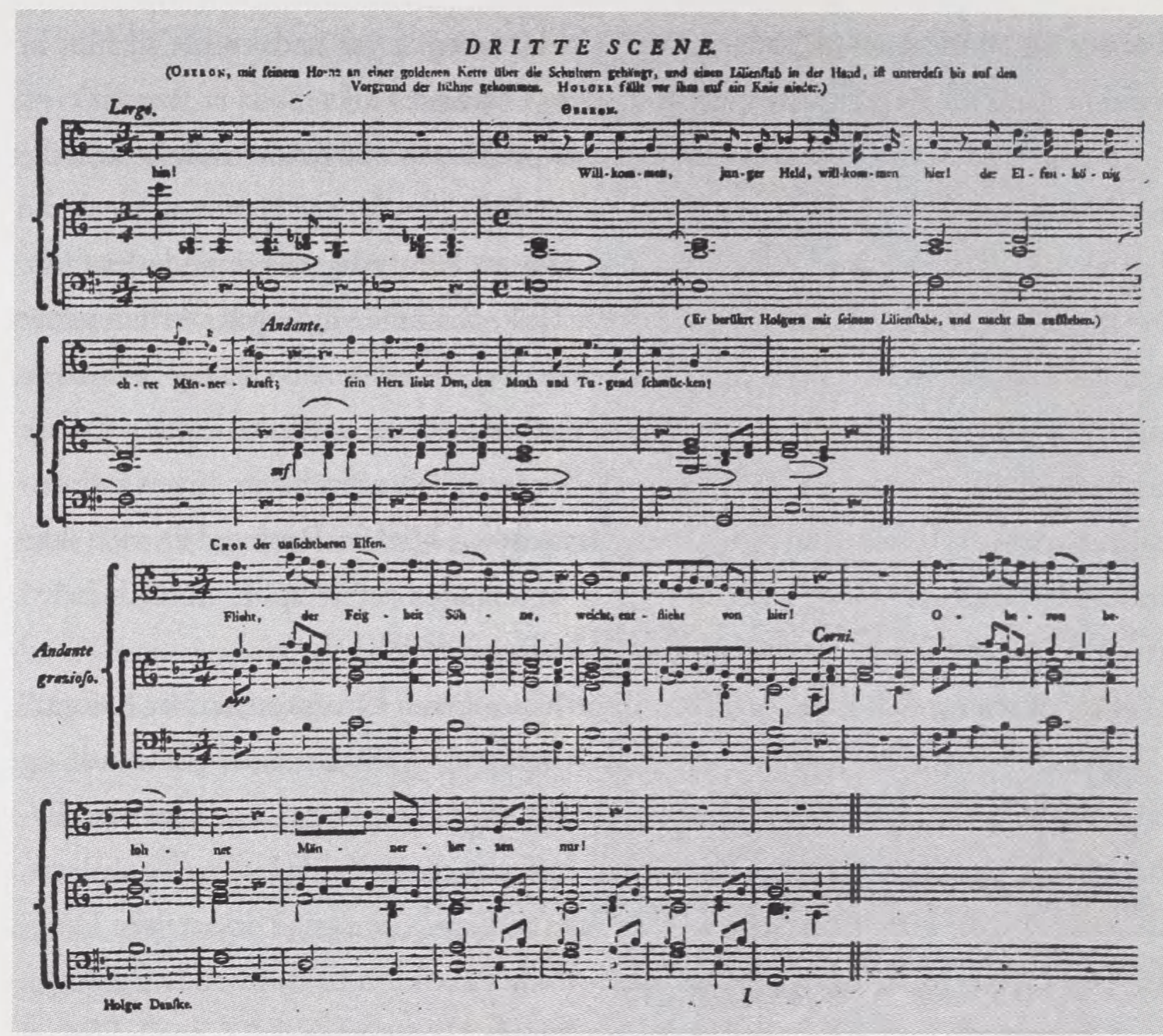

Mødet mellem Oberon og Holger Danske og Kor af usynlige alfer. Fra operaen Holger Danske, 1790.

Knud Lyhne Rahbek - igennem mange år byens førende teateranmelder - lagde for med kritikken:

„Allerede ved det allerførste Indbrud af dette Skuespilslags yttrede Anmelderen sin Meening om dets farlige Indflydelse paa meer end paa vor Skueplads, hvis det nogen Tid blev herskende hos os. Dog havde han det Haab, at dette i Betragtning af disse Skuespils ødelæggende Kostbarhed ikke lettelig vilde skee. Men da man nu efter hinanden giver to nye og kostbare Operaer paa en Tid, da hver Skiærv af Statens Kasse maae være syvfold helligere end nogentid, synes dette Onde at indbryde med en saadan Vælde, at det er høi Tid, at ikke blot Skuepladsens, men ogsaa Fædrelandets Venner opløfte deres Røst ... Vor Skueplads' ødelæggelse er en mindre Ting i Sammenligning med den Skade slige tankeløse, smaaglimrende Forlystelser gjøre vor national Caracter, idet de vænne os til Tankeløshed, Blødagtighed og Overdaad ... slige Abespil vare det Middel, hvorved Romerne blev betaget den sidste 
Levning af deres fordums Storhed og Manddom.“

Den fornuftige og velafbalancerede professor medicinae Johann Clemens Tode, der stod i en anden lejr - og som i øvrigt jævnthen ytrede sig i hovedstadens periodica $\mathrm{i}$ alle mulige anliggender - replicerede:

„Himlen bevare mig i Naade for at være Operaers Advokat ... Jeg er ingen større Ven af Operaen end jeg bør være. Men at vi ingen Opera skulde have, det ønsker vist ingen billigt tænkende Skuespilynder ... Man maae ikke giøre saadan Skraal ... og naar det ovenikøbet er en Original Opera, et Arbeide af en af vore allerbedste Digtere, som giver Anledning til en patriotisk Feber, paa det der ikke kan siges, det er Nid og Misundelse, der patriotificerer os, og at Originaler ere det vi mindst kunne taale at se fremelskes..."

P. A. Heiberg, som var en skrap og vittig modstander af opera, førte utvivlsomt en af hovedstadens spidseste penne. Hans udprægede talent for begavede giftigheder måtte placere ham midt i denne strid. Han havde tidligere i forbindelse med opførelsen af Naumanns og Charlotte Dorothea Biehls opera Orfeus og Eurydike skrevet parodien Mikkel og Malene for at latterliggøre operaen og dens unatur. Orfeus blev til den fordrukne kusk Mikkel, den skønne Eurydike til den buttede Malene-mor. Parodierende Holger Danske skrev Heiberg nu en blændende og vittig tekst Holger Tyske, der stavelse for stavelse følger forlægget og derved passer til Kunzens musik. Holger er blevet til en skomagersvend, den skønne prinsesse Rezia bliver til den tyvagtige Øllegaard, sultanerne bliver til byfogeder i en dansk provinskøbstad, Almansaris bliver til en gammel giftesyg faster, det gyldne horn bliver til spansk tobak og den straffende dans som følge heraf til det straffende nys! - altsammen meget godt i tråd med Heibergs udtalelse om genren i almindelighed: „Opera bekriger al Sandsynlighed“.

Samtidig hermed kunne Aftenposten aftrykke 8 epigrammer affattet af Rahbek i venners festlige - og måske ikke mindst tørstige - lag. Man havde været sammen, drukket tæt og moret sig med at lave vers omkring Holger Danske. Uden Rahbeks vidende var de havnet hos Aftenposten. Ingen af dem er synderlig gode, endsige morsomme, hvilket følgende smagsprøve kan tjene som eksempel på:

„Din Holger Danske fik Du færdig i en Ruf,

Snart Erik Ejegod skal færdig være

Den Hurtighed gjør Dig i Sandhed Ære,

Men gjør Dit Arbeid Dig det samme, UF!“ 
Baggesen blev rasende. I piecen Til det virkelige Publicum skrev han følgende:

„Herr Rahbek og Compagnie kan recensere, kriticere, prologuere, parodiere, epigrammatisere herefter saa meget og pudseerligt de ville. Det skal ikke bekymre mig; jeg bliver ligefuldt ved at see roligt ligefrem. Vee den Konstens Dyrker, hvis svagsynede Sjel ikke seer andet Ideal til Fuldkommenhed, end det livløse Uhyre, hans Hukommelse kan sammenlime af Lærebøgers og Recensioners tørre, skjæve, af Vinden let bortviftede Theori-Spaaner! og tre Gange vee den, hvis lille Hjerte føler Journalers Roes og Smaapublicummers Bravo som sit Maal og sin Belønning“.

Baggesen blev bebrejdet ikke at have valgt et nordisk emne, og sandt at sige nævnes Danmark også kun et enkelt sted i handlingen. Baggesen omgikkes tysktalende adelskredse, som gerne så operaen etableret, så i denne forbindelse hjalp det ham fedt, at han var født i Korsør - og i øvrigt var komponisten jo også en „tydsker“!

Modsætningen mellem dansktalende og tysktalende var af ældre dato end som så; den rakte i hvert fald tilbage til Struensee-tiden og blev efter regeringsskiftet 1784 mere udtalt. Bernstorff havde besat næsten alle gesandtskabsposter og ikke så få af de mere betydningsfulde stillinger indenfor centraladministrationen og ved hoffet med nærmere eller fjernere pårørende eller tilhængere. Grevinde Schulin til Frederiksdal skrev $\mathrm{i}$ et personligt brev fra 1790 til broderen F.C. von Warnstedt utvivlsomt meget rammende herom:

„Bernstorfferne danner på en altfor stødende Maade en særlig Sekt for sig ved at bevidne deres Ringeagt for Landets Sprog og alt, hvad der hører sammen med Folkets sunde og solide Fornuft".

Bernstorffs egen Svoger - den bekendte digter F.L. greve Stolberg var kommet for skade at omtale landet som „det forhadte Danmark“ og dets hovedstad som „Aarhundredets største Morads, hvor han hellere vilde give alt Får i Naturen Navn end optælle alle de tobenede Æsler, der fandtes i København“.

Havde der været storm før, blev det til et orkanagtigt hyl, da Kieler-professoren C.F. Cramer oversatte Holger Danske til tysk med tilegnelse til Wieland og i et forord hævede Baggesen over den forgudede Ewald. Samtidig udkom Ernst Philipp Kirsteins måske ikke så gennemtænkte Ausrufungen veranlasst durch Holger Danske und Holger Tyske:

„Hvilken Gæringens Aand er pludselig opstaaet? Hvilket ubegribeligt Raseri har grebet Skønaanderne, de lærde og Patrioterne? Hvad ser jeg? Fjender bliver til 
Venner. Landsforviste tages atter til Naade. Der flyder Gift fra deres Læber, og hvert af deres Ord høres dog kun med Beundring. Hvad er der da sket? Hvorfor staaer de der saa blege allesammen? Hvorfor er Staten rystet? Hvorfor er Sæderne krænket? En dansk Digter har digtet en Opera. Middelmaadighedens Grænser er overskredne. Men det er ikke alt. En tysk lærd, greben af ædel, umiddelbar Begejstring rost ham, Nationen og dens Sprog ... Den unge Ørns Vinger skal stækkes, før den slukker sin Flammetørst, 'før den begynder sin Flugt mod Solen ... Vi maa angribe ham hedder det videre, som om han var en Fremmed, en Tysker. Ganske vist tilhører han Danmark helt og holdent. Ingen Draabe fremmed Blod rinder i hans Aarer. Men er han alligevel en Tysker, Jovist. Der er Tyskere blandt hans Venner, en Tysker har oversat ham, han er en Gallilæer".

En anmelder fløj fluks i blækhuset; tonen skærpedes mærkbart:

„Dette usle Smøreri indeholdes paa 8 Sider. En slig Skribler kan ikke revses bedre end ved Taushed og Foragt, og dersom denne usle Synder var den eeneste i sit Slags, dersom denne ubegribelige Frækhed, der hersker i Piecen var blot dette individuelle Krybs særegne Kaadhed og Dumdristighed; aldrig skulde vi da i disse Blade have omtalt dette ephemeriske Produkt eller spildt endog et eeneste Øieblik paa dets pygmæiske Forfatter. Nu derimod, da der desværre ere flere der skryde i samme Tone ... da vi i Følge dette ærkedumme Skraal og Væv have at frygte for at vore Presser skal besudles med meere af samme Surdey, saa ville vi strax her angive Tonen, i hvilken vi ville tale med denne og andre slige Ordgydere, Skraalhalse og Markskrigere ....".

En anden var mere kortfattet:

„Den ubegribelige Tomhed, det saa totale Intet i disse Blade, gjør det aldeles umuligt at sige noget derom".

Injurierne føg om ørerne på københavnerne. Holger-fejdens akter, der består af 60 - 70 piecer, recensioner, artikler, indlæg og replikker er en endeløs række af smålige, intolerante og direkte injurierende udsagn, begavede og mindre begavede analyser. Den debat, der var lagt op til om operaen som kunstform, om operaens æstetik, udeblev; den blev kvalt i grovheder og personligheder af værste skuffe. Disse udsagn er naturligvis ganske morsomme og festlige at læse i dag, men de kvalte desværre dengang Baggesens og Kunzens opera. En egentlig saglig, mere detailleret kritik var der kun få og små tilløb til, bl.a. fordi der var tale om en i Danmark for- 
holdsvis ny kunstart, som man havde svært ved at forholde sig til på grund af manglen på veldefinerede musikalsk-æstetiske kriterier. Rahbek og andre fra samme lejr forstod ikke, at man måtte stille andre krav til en operatekst end til en skuespilditto, - han ville absolut "prøve Operaen efter Dramaets Regler“. Udover at finde operaen unaturlig, for dyr og mange andre ting, fandt han dette specielle værk moralsk anstødeligt:

„Der er en Overflødighed af Handling, en Mængde af Personer og forskiellige Tildragelser, som her maae sammenpresses inden de snævre Grænser af 3 Operaacter ... det er en Labyrint, hvoraf ingen finder ud, der ei har Wielands Oberon til Ledetraad. Emnet ... har paalistet Hr. Baggesen den wielandsk anstødelige Scene imellem Almansaris og Holger; dadler man allerede Wieland med Rette, fordi han saa gierne opflammer sine Læseres Indbildningskraft med Beskrivelsen af deslige vellystige Scener, da var det sikkert endnu mere at ønske, at Holgers Digter havde vogtet sig for at fremstille dem for vore Sanser og med de mest glødende Farver at udmale, hvad hans Forgænger kun havde anlagt. Heller ikke kan Anmelderen tilbageholde sin Forundring, at Skuespillenes Censor, Sædernes og Smagens nidkære Talsmand, har ladet denne Scene gaae uanmærket bort ...".

Kunne man ikke få folk til at forstå, at opera generaliter set var unatur, at denne opera specialiter var for rodet og for dyr, så kunne man jo altid forsøge at ramme stykket på moralen. Et andet interessant udsagn vedrørende det moralsk anstødelige lå på linie med Rahbek:

„Naar man endelig vil have Opera, og skal have Opera, og ikke kan være lykkelig uden Opera, saa er det vist nok bedre at man faaer sig Originaler end Aliner, bedre at gode Digtere give en Holger Danske, end at vi skulle nødes at gumle paa en Orpheus ... [dette med allusion til Schulz” opera „Aline“ og til Naumanns "Orpheus"] Skjøn er i høj Grad den vellystige Almansaris. Hendes Sang er især udmærket mesterlig ... Alligevel bør erindres, at just ved det denne Scene har, bliver den farlig for den, hvis Blod endnu flyder let i Aarerne; ... thi den groveste sandselige Vellyst viser sig her uden det mindste der kunne støde tilbage eller advare“.

Cramer - den musikinteresserede Kieler-professor, selv en original kunstnersjæl - skrev en anmeldelse af værket for det tyske publikum i Altonaer Mercur.

„Holger Danske holder jeg, hvad Poesien angaar for et Mesterstykke af en Opera ... og hvilken Rigdom af musikalske Ideer! hvilken Kundskab i Harmonien! hvilken 
Overflødighed af fortryllende Sang, af hvad der her paa Theatret gjør Virkning, af fuldglimrende Instrumentalmusik, af betydningsfulde Recitativer, af Sylphemelodier, af Schulzisk Popularitet! mange Stykker deraf lærte man ogsaa strax udenad og i Vinteren 1789 hørte man dem som Folkesange paa alle Kiøbenhavns Gader, Stræder og Vagtparader“.

Et spændende dokument - ikke mindst er naturligvis den sidste bemærkning interessant! - - Baggesen var udmærket klar over, at hans særprægede ven Cramer undertiden kunne være ham et „dyrt bekendtskab“:

„Jeg kender indtil nu ingen Person paa Jorden, hvis Ejendommeligheder og Egenart har viklet mig ind i en Strøm af Ubehageligheder - og dette uden at ville det endsige vide det“.

Cramers oversættelse af Baggesens tekst afstedkom et voldsomt raseri fra dansk side. Han var kendt i hovedstaden, hvor han ikke var velset; med klar allusion til Cramer og de holstenere, der snarere følte sig som tyskere end som danskere, hvislede P.A. Heiberg:

„Erfarenheden har lært mig at alle de, hvis Modersmaal er tydsk, vil hellere anses for Undersaattere af det hellige romerske Rige end af Danmark og de foragter det danske Sprog og alt, hvad dansk er, tvært imod al Pligt og Billighed ... for en dansk Digter er det aldrig noget Tab ikke at blive oversat af en Mand, om hvem man, naar han endog skal bedømmes allermildest, i det mindste maa sige, at han ikke forstår dansk."

Cramer reagerede med skriftet Baggesen - et skrift på 20 sider vedrørende Holger-fejden. Cramer tilskrev den negative holdning til Baggesens værk, at der var tale om kollegial misundelse. Han fandt, at Holger Danske var et mesterværk - „Caviar for Hoben" - og benægtede, at der var tale om nationale modsætninger imellem ham og danskerne. Dette skrift gjorde bl.a. Werner Abrahamson så indædt rasende, at han forfattede en anmeldelse i de „lærde Efterretninger“ - et 13 siders lærestykke $\mathrm{i}$ bidende ironi.

I maj - helt nøjagtigt d. 24., knap 2 måneder efter premieren - blev det for meget for Baggesen; han tiltrådte sin „labyrintiske rejse“ og efterlod Kunzen i København midt i balladen.

Kunzen selv sagde ingenting - - og dog. I august 1789 - altså et lille halvt år efter premieren på et tidspunkt, hvor operafejden var ved at synge på sidste vers, eller 
rettere antog en anden karakter, idet den nu blev til en national dansk/tysk konfrontation - indrykkede han en annonce i Adresseavisen. Han opfandt en „Langøret Fætter“ i Stockholm, der havde sendt ham sin komposition Holger Tyske. Kunzen skrev d. 11. august 1789 under „Musikalier til Salg“ følgende subskriptionsindbydelse:

„Min Fætters Komposition til Holger Tyske med hans egne og Udgiverens Anmærkninger. Under denne Titel udkommer med det første et lille Værk, der ogsaa vil være af Interesse for dem, der hverken kan spille eller synge ... “ [!]

Værket udkom aldrig, og det er måske også et spørgsmål, om Kunzen virkelig har tænkt sig, at det skulle udkomme.

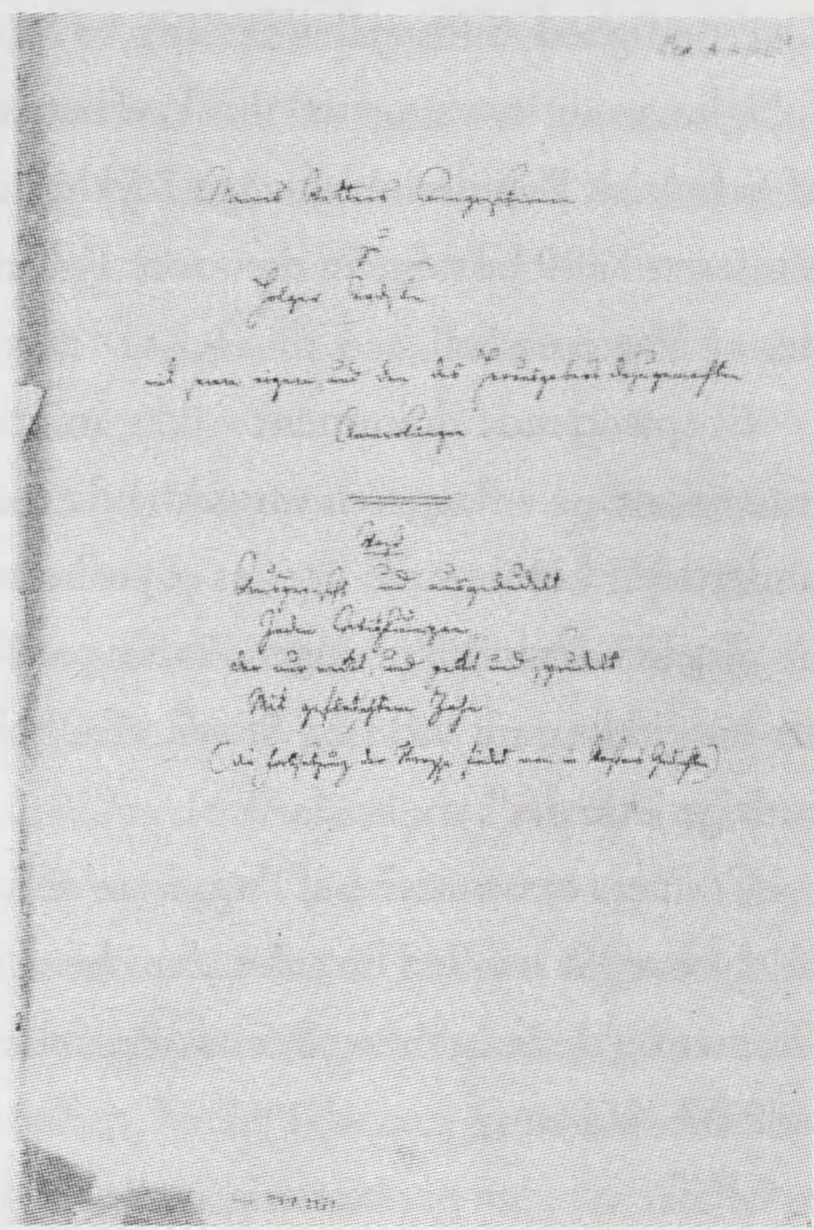

Titelblad fra Kunzens musikalske parodi Min Fatters composition til Holger Tydske, 1789. I oktober 1789 blev det så også for meget for Kunzen, der måske også på denne baggrund havde noget svært ved at få øje på sine fremtidige muligheder i København. Det nævnte „stridsskrift“ fra Kunzens hånd, som befinder sig på Det kongelige Bibliotek i København, er i sig selv det sirligste, fornemste skrift hele denne pinlige operastrid frembragte. I den fingerede komposition giver Kunzen sin harme frit løb. Fremfor alt var han forbitret over, at Heiberg havde stillet et begynderarbejde af Claus Schall over Kunzens værk, blot fordi Schall var dansker. Kunzens lille komposition er i sig selv et lille mesterværk - en parodi på alle de skrivefejl og uhyrligheder, der bl.a. var en del af i det nævnte begynderarbejde af Schall: parallelle kvinter, umulige modulationer, usangbare intervaller, dårlig deklamation med forkerte tekstbetoninger etc. etc.

Holger Danske blev kvalt i en operafejde, som i lige så høj grad var en sprogfejde og en politisk kamp. Baggesens og Kunzens mesterværk blev den for så vidt tilfældige gnist, der antændte en velvoksen krudttønde med krudt, der var tørt fra Struensee-tiden; operaen blev desværre skrevet/komponeret i en overordentlig føl- 


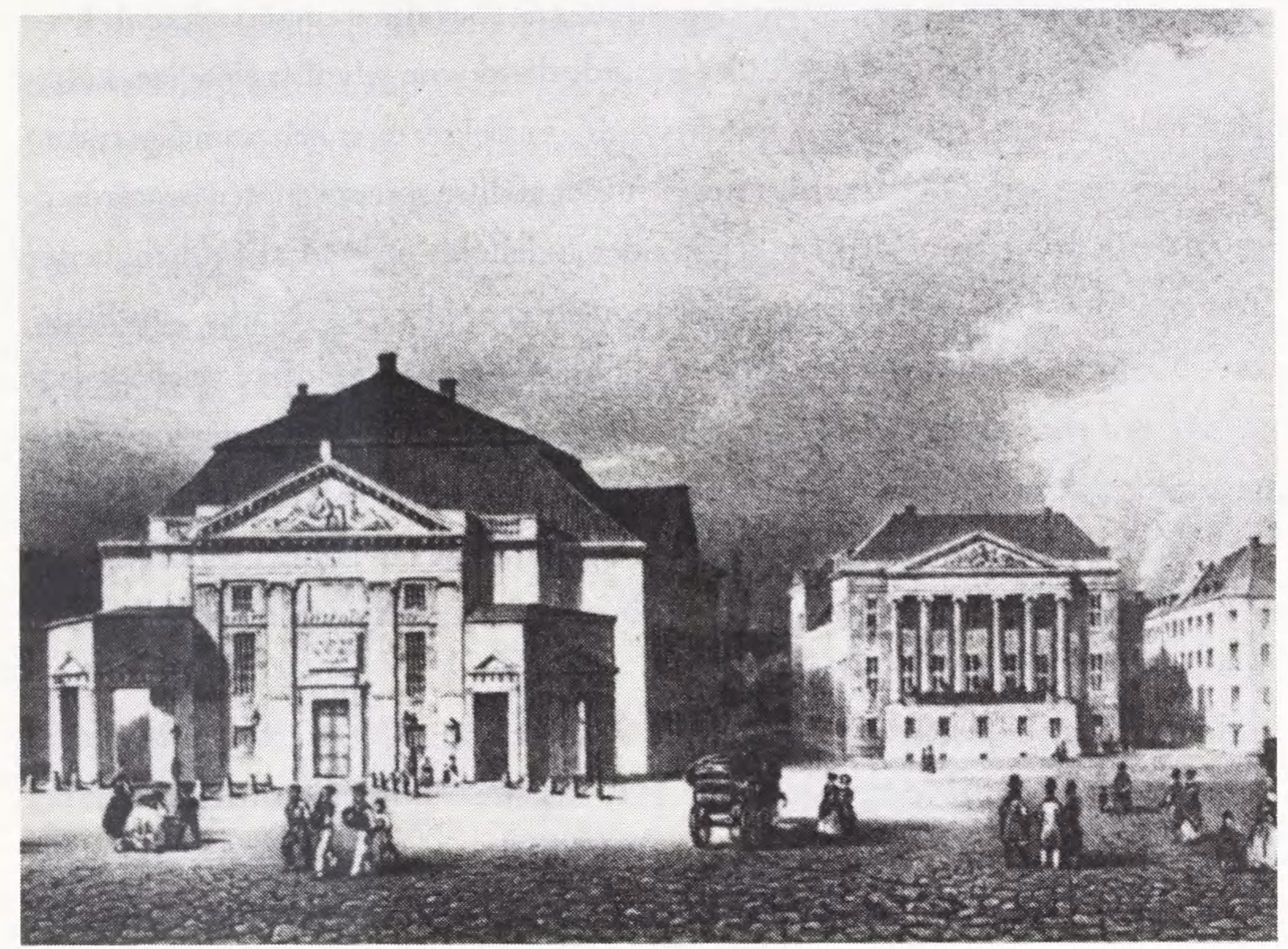

Det kgl. Teater, som det så ud i de år, hvor F.L.Ae. Kunzen bestred kapelmesterstillingen.

som periode i dansk historie: efter regeringsomdannelsen i 1784, samtidig med gennemførelsen af landboreformerne og den kortvarige krig med Sverige 1788, midt i debatterne omkring trykkefriheden etc. Holger Danske blev ved skæbnens ugunst den faktor, der udløste årtiers spændinger af politisk, sproglig, kulturel og social art, - katalysator for det uundgåelige opgør, der måtte komme. Værket blev direkte årsag til en fejde, der ikke alene viste divergenserne imellem en samtidig tysk-inspireret aristokratisk og en borgerlig dansk kunstopfattelse; den udviklede sig til at blive den første åbne dansk-tyske nationale konfrontation, og den fik eftervirkninger langt ind i det næste århundrede.

Holger Danske forårsagede - i det franske revolutionsår 1789 - den danske revolution - nota bene: en revolution, der ikke kappede hovederne af fyrste og aristokrati, som det så uciviliseret gik for sig i det sydlige udland, men derimod en revolution, som trods alt var en civiliseret - omend ofte underlødig - kamp på pen og blæk. Fra dansk side beskyldtes „tydskerne“ oftest for at være storpralende, overlegne og bedrevidende, for at være fulde af foragt for dansk sprog og kultur, for protektionisme og 
nepotisme i forbindelse med stillingsbesættelser, for bevidst at undertrykke alt hvad der var dansk. „Tydskerne“ fandt på deres side danskerne selvtilstrækkelige, kulturelt middelmådige, i besiddelse af mindreværdskomplekser og et helt urimeligt tyskerhad. Debatten var, som det turde være fremgået af disse spredte citater, overordentlig følelsesladet; selvom den fra begge sider indeholdt et væld af urimeligheder, indeholdt den dog også fra begge sider momenter af klarsyn, - måske „am Ende“ ikke mindst fra de få danskere, der - ved i fiktive indlæg at fremføre velovervejede kritiske ord vedrørende iøjnefaldende danske svagheder - derved indirekte vendte en berettiget kritik imod egne rækker i den klare hensigt at få landsmændene til at tænke sig om. På baggrund af den politiske og kulturelle udvikling i Danmark i det næste århundrede må man ud fra dette synspunkt sige, at den ublodige danske „revolution“ lykkedes.

Holger Danskes senere skæbne efter de 6 opførelser i 1789 har været såre besynderlig; en opførelse af første akt ved en af Enkekassekoncerterne d. 24. november 1804 - altså efter Kunzens ansættelse som kgl. kapelmester i København - fik ingen effekt, og operaen blev aldrig siden en del af repertoiret på Det kongelige Teater. Værket lå gemt, indtil Kunzen-biografen Martienssen foranledigede en koncertant opførelse i 1912 i Cæciliaforeningen under ledelse af Frederik Rung og under medvirken af bl.a. Tenna Kraft. Derefter blev det endnu engang glemt, indtil det blev opført nogle gange på Det kongelige Teater i 1941. Poul Kanneworff instruerede, Harald Lander lavede koreografien og Johan Hye-Knudsen havde den musikalske ledelse. Solister var bl.a. Thyge Thygesen som Holger og Edith Oldrup som Rezia. I samme indstudering blev operaen så genoptaget i 1944 - og pudsigt nok, - nu 150 år senere blev den under 2. Verdenskrig betragtet som en national dansk manifestation overfor den tyske besættelsesmagt - - - med operaens historie in mente må det da vist siges at være skæbnens blodige ironi!

Samtidig med Martienssen beskæftigede også Hermann Kretzschmar sig med værket, som han omtalte som „die bedeutendste romantische Oper grossen Stils aus dem 18. Jahrhundert"! Senere har flere historikere beskæftiget sig med Holger Danske alle med en positiv bedømmelse: Torben Krogh (1924), Sven Lunn (1941 og 1944), Børge Friis (1943), Anna Amalie Abert (1978) og endelig har Nils Schiørring - den største kender af den danske musikhistorie - ment, at Holger Danske må anses som „det betydeligste musikdramatiske værk, der har set lyset herhjemme i 1700-tallet“. 
1984 tog så Danmarks Radios kor- og orkesterchef, Per-Erik Veng, i samarbejde med undertegnede initiativet til en koncertant opførelse af Holger Danske ved en af DR's Mandagskoncerter, der fandt sted d. 21. maj. Efter ved denne lejlighed at være genopdaget for 3. gang er værket nu endelig med indspilningen af en CD i 1995 kommet for at blive - og for at blive anerkendt for, hvad det er: en særdeles interessant brik i operaens historie og et af de mest spændende og mærkværdige værker, der er skrevet for den danske skueplads overhovedet. 